\title{
Influence of health care practices on the burden of caregiver mothers
}

\author{
Influência das práticas de atenção à saúde na sobrecarga de mães cuidadoras \\ Influencia de las prácticas asistenciales en la carga de las madres cuidadoras
}

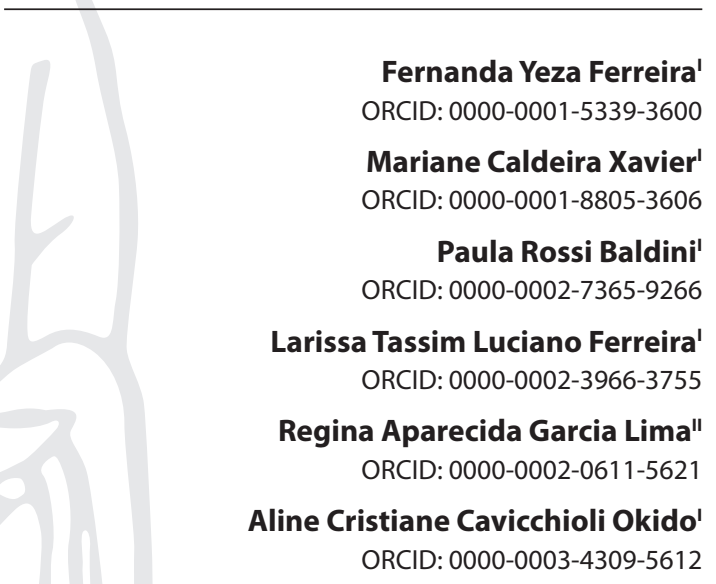

'Universidade Federal de São Carlos. São Carlos, São Paulo, Brazil. "Universidade de São Paulo. Ribeirão Preto, São Paulo, Brazil.

How to cite this article: Ferreira FY, Xavier MC, Baldini PR, Ferreira LTL, Lima RAG, Okido ACC. Influence of health care practices in the burden of caregivers mothers. Rev Bras Enferm. 2020;73(Suppl 4):e20190154. doi: http://dx.doi.org/10.1590/0034-7167-2019-0154

Corresponding author: Aline Cristiane Cavicchioli Okido

E-mail: alineokido@ufscar.br

EDITOR IN CHIEF: Dulce Aparecida Barbosa ASSOCIATE EDITOR: Rafael Silva

Submission: 03-01-2019

Approval: 09-26-2019

\section{ABSTRACT}

Objectives: to explore the influence of health care practices on the burden of caregiver mothers of children with special health needs. Methods: observational, analytical, crosssectional, quantitative study. Participation of 100 caregiver mothers, who responded the following instruments: characterization instrument; Burden Interview for Informal Caregivers; Perceptions of Family-Centered Care - Parents version; Evaluation Instrument for Primary Care - Child Version. For statistical analysis, were used the Spearman's Correlation and univariate and multivariate linear regression analysis. Results: the mean burden score was 47.99. There was a negative correlation between the burden and the domains of collaboration and support of the Perceptions of Family-Centered Care scale. In the multivariate linear regression model, the longitudinality variable maintained a significant relation with the burden $(p=0.023$ ) Conclusions: a shared, longitudinal and integrated care between families and health services can ease the burden of caregiver mothers.

Descriptors: Child; Nursing; Caregivers; Mothers; Health Services.

\section{RESUMO}

Objetivos: explorar a influência das práticas de atenção à saúde na sobrecarga das mães cuidadoras de crianças com necessidades especiais de saúde. Métodos: delineamento observacional, analítico, transversal, de abordagem quantitativa. Participaram 100 mães cuidadoras respondendo aos seguintes instrumentos: instrumento de caracterização; Escala de Sobrecarga para Cuidadores Informais; Percepção do Cuidado Centrado na Família- versão pais; Instrumento de Avaliação da Atenção Primária à Saúde - Versão Criança. Para análise estatística utilizou-se correlação de Spearman e análise de regressão linear univariada e multivariada. Resultados: o escore médio da sobrecarga foi 47.99. Houve correlação negativa entre a sobrecarga e os domínios colaboração e suporte da escala de percepção do cuidado centrado na família. No modelo de regressão linear multivariado, a variável longitudinalidade manteve relação significativa com a sobrecarga ( $p=0.023)$. Conclusões: um cuidado compartilhado, longitudinal e integrado entre famílias e serviços de saúde pode amenizar a sobrecarga das mães cuidadoras. Descritores: Criança; Enfermagem; Cuidadores; Mães; Serviços de Saúde.

\section{RESUMEN}

Objetivos: explorar la influencia de las prácticas de atención a la salud en la sobrecarga de las madres cuidadoras de niños con necesidades especiales de salud. Métodos: investigación observacional, analítica, transversal y cuantitativa. Participaron 100 madres cuidadoras respondiendo a los siguientes instrumentos: instrumento de caracterización; Escala de Sobrecarga para Cuidadores Informales; Percepción del cuidado centrado en la familiaversión padres; Instrumento de Evaluación de la Atención Primaria a la Salud - Versión Niño. Para el análisis estadístico, se utilizó la correlación de Spearman y el análisis de regresión lineal univariado y multivariado. Resultados: la puntuación media de la sobrecarga fue de 47.99. Hubo correlación negativa entre la sobrecarga y los dominios colaboración y soporte de la escala de percepción del cuidado centrado en la familia. En el modelo de regresión lineal multivariado, la variable longitudinalidad mantuvo una relación significativa con la sobrecarga $(p=0.023)$. Conclusiones: una atención compartida, longitudinal e integrada entre familias y servicios de salud puede amenizar la sobrecarga de las madres cuidadoras. Descriptores: Niño; Enfermería; Cuidadores; Madres; Servicios de Salud. 


\section{INTRODUCTION}

Children with special health needs (CSHCN) is a broad definition for different health problems of varying complexity and care demands $s^{(1-2)}$. These children need ongoing attention from family members and health professionals beyond what is required by children in the same age group ${ }^{(3)}$. The population census of the Brazilian Institute of Geography and Statistics (Portuguese acronym: IBGE) refers to this group as children with disabilities, and they represent approximately a quarter of the Brazilian child population ${ }^{(4)}$.

Generally, mothers assume full-time responsibility for the care delivery and therapy management ${ }^{(5)}$. Performing the caregiver role together with domestic responsibilities potentiates financial difficulties, social isolation, depressive symptoms and marital dissatisfaction, thereby generating overload ${ }^{(6-7)}$. Hence the relevance of tracking the tension of caregiver mothers and rethinking healthcare practices to these clients in order to review the care focused on fragmented procedures and strengthen a practice based on accountability and attachment ${ }^{(8-9)}$.

Some healthcare practices are associated with positive results, such as improved interaction between families and health professionals and greater satisfaction with the healthcare received, with highlight to effective care coordination and the family-centered care model $^{(10)}$. Care coordination is the effective articulation and integration between family and health professionals of the various institutions involved in care provision ${ }^{(11)}$ in order to ensure continuity of care. In the family-centered care model, the main focus of care is the individual and the family, which is also an essential source of support ${ }^{(12)}$. Other potential healthcare practices are long-term therapeutic relationships between health professionals and users with the creation of a bond from the perspective of longitudinality ${ }^{(13)}$.

Considering the above, the present study started from the following research questions: "Does the practice of family-centered care by health services influence the physical, emotional and social burden of caregiver mothers of CSHCN?"; "Does the practice of longitudinal care by health services influence the physical, emotional and social burden of caregiver mothers of CSHCN?"; "Does the care coordination by health services influence the physical, emotional and social burden of caregiver mothers of CSHCN?".

The development of this study is justified by the importance of quantitatively analyzing the influence of these healthcare practices on the burden of caregiver mothers of CSHCN.

\section{OBJECTIVES}

To explore the influence of healthcare practices on the physical, emotional and social burden of caregiver mothers of CSHCN.

\section{METHODS}

\section{Ethical aspects}

The study was approved by the Research Ethics Committee of the institution and all ethical procedures for research involving human subjects were followed according to Brazilian Resolution $466 / 2012$ of the National Health Council.

\section{Design, location and period of the study}

This is an observational, analytical, cross-sectional, quantitative study ${ }^{(14)}$. It was performed between May 2017 and April 2018. The social context of production of empirical material consisted of four outpatient institutions that provide multiprofessional care to CSHCN in a municipality in the inlands of the state of São Paulo.

\section{Population or sample; inclusion and exclusion criteria}

The study included 100 caregiver mothers of CSHCN. The eligibility criteria were: to be responsible for most care of CSHCN aged from zero to 12 incomplete years, and to be over 18 years old. The exclusion criterion was: care experience for CSHCN under three months. The classification of children followed the Child and Adolescent Statute ${ }^{(15)}$. No screening instrument was applied to CSHCN because the institutions were specialized, that is, the fact that the child was in follow-up treatment at these institutions already characterized them as CSHCN. However, researchers were oriented to pay attention to situations in the first consultation. The number of participants was according to the following recommendations: to achieve an alpha significance level of 5\% and power of $80 \%$, were necessary 10-15 participants for each factor of interest associated with physical, emotional and social burden, known as the ratio of cases to IVs (Independent Variables) (16). As presented below, there were six factors of interest in the present study, thereby resulting in a minimum of 60 participants and a maximum of 90 .

\section{Study protocol}

Initially, the institutions were contacted, the project was explained and authorization to conduct the study was requested. Caregiver mothers were contacted in the institution, during their presence for follow-up treatment. After reading the informed consent form, mothers who agreed to participate in the study responded to an electronic form in a reserved space (duration of approximately 30 minutes). The application of the form was intermediated by three previously trained researchers.

The electronic form included the following instruments: sociodemographic characterization instrument, Burden Interview (BI) - Burden Scale for Informal Caregivers ${ }^{(17)}$, Perceptions of Family-Centered Care - Parents, Brazilian version (PFCC-P Brazilian version) ${ }^{(18)}$ and Primary Care Assessment Instrument (PCATool Child Version) ${ }^{(19)}$. Only the longitudinality and coordination attributes of the PCATool-child version instrument were evaluated. In addition, this instrument was answered only by caregiver mothers who claimed to use Primary Care services of the municipality. Therefore, out of the 100 study participants, 59 responded to this instrument.

The Burden Interview contains 22 questions, which were answered using a Likert scale ranging from 0-4 points. The final score can range from 0 to 88 , and the higher the final score, the higher the caregiver burden ${ }^{(17)}$. The PCATool- child version is a Likert scale with five response possibilities. In this instrument, it is possible to transform the value obtained into a 0 - 10 scale, where values $\geq 6.6$ are considered high or satisfactory and values $<6.6$ are considered 
low or unsatisfactory ${ }^{(19)}$. The Brazilian version of the PFCC-P is also a Likert scale ranging from 1-4 points. The final score is obtained from the sum of all questions and division by the number of questions with the following classification: score of 1-1.9=never practiced in the unit; $2-2.9=$ sometimes practiced in the unit; 3-3.9=usually practiced; and $4=$ always practiced in the unit ${ }^{(18)}$.

Before the analyzes, was calculated the internal consistency coefficient (Cronbach's a) of all instruments and their domains. Cronbach's a values were considered acceptable from $0.60^{(20)}$. High internal consistency was found for most instruments, except for the domain 'respect' of the PFCC-P, Brazilian version and it was removed from the analyzes. As the six items in this domain concern family rights in the hospital, and there were CSHCN who had not been hospitalized previously, it may have occurred an inappropriate interpretation of items.

The dependent variable or response variable was the physical, emotional and social burden of informal caregivers of CSHCN, classified as numerical variable. The independent variables were those related to health care practices, namely: overall score of the perceptions of family-centered care (PFCC- overall); support domain score (PFCC-support); collaboration domain score (PFCCcollaboration); longitudinality attribute score (Longitudinality) and care coordination attribute score (Coordination).

The control variables introduced in the multivariate analysis derived from the characterization instrument. Thus, the variable "residents in the household" is a discrete numerical variable corresponding to the number of people living in the same household as CSHCN (including the child him/herself). The variable"caregiver's education" is the number of complete years of formal education. "Marital status" was considered according to the presence or absence of a partner in the same household (dichotomous categorical variable). "Religious belief" was treated as a dichotomous categorical variable (Yes/No). For the variable "occupation", were considered two response options (paid work and other forms of work).

\section{Analysis of results and statistics}

After completing data collection, the database was exported to The SAS System for Windows (Statistical Analysis System), version 9.2, where analyzes were performed. Initially, were performed the Shapiro-Wilk and Kolmogorov-Smirnov normality tests and the normal distribution of variables was not found. Therefore, variables were ranked for use in the linear regression analysis. In the descriptive phase of statistical analysis, numerical variables were described from measures of central tendency, variability and position.

In the analytical stage, was calculated the Spearman correlation coefficient between the burden score and the independent variables. Univariate and multivariate linear regression analyzes were performed with the Stepwise variable selection criterion. A significance level of $5 \%$ was adopted for the tests ${ }^{(21)}$.

The analysis of assumptions of univariate and multivariate linear regression was performed as follows: to check the normality of regression residuals, were constructed histogram graphs, which confirmed the normal distribution and non-asymmetry of standardized residuals; the homogeneity of variance was identified from the dispersion diagram between residuals and the standardized predictor values, and the points spread homogeneously in the diagram without discrepant values; the absence of autocorrelation of residuals was confirmed by Durbin-Watson statistics, as the calculated values remained close to 2.0 , an indication of the absence of autocorrelation.

In multivariate regression, in addition to the assumptions presented above, was also found absence of multicollinearity. Therefore, were calculated the Variance Inflation Factor (VIF) values of each variable. As VIF values were close to 1.0, was confirmed the non-collinearity between the independent variables of the regression model.

\section{RESULTS}

The study included 100 caregiver mothers of CSHCN. The mean physical, social and emotional burden of these caregiver mothers was 47.99, standard deviation 13.07, minimum score 25, median 46 , maximum score 84 , first quartile 39 and third quartile 56. Table 1 shows the mean score, standard deviation, median, quartiles and maximum and minimum score of variables related to health care practices.

The correlation matrix involving the independent variables related to health care practices and the response variable are shown in Table 2. There was a negative correlation between the caregivers' physical, social and emotional burden score and the following variables: PFCC-collaboration, PFCC-support and Longitudinality.

Univariate linear regression analysis was used to study separately the relationship of independent variables with the mean score of physical, social and emotional burden of CSHCN' caregivers, as shown in Table 3.

Next, the statistically significant variables entered the multivariate linear regression model by the Stepwise Backward Wald method. The Longitudinality variable maintained a significant relationship with the physical, social and emotional burden score of CSHCN' caregivers $(p=0.023)$, that is, $\mathrm{CSHCN}^{\prime}$ caregivers with the highest burden scores were those who obtained the lowest scores for the longitudinality attribute in Primary Health Care.

Table 1 - Distribution of scores of variables related to health care practices, São Carlos, São Paulo, Brazil, 2017-2018

\begin{tabular}{lccccccc}
\hline Variables & $\begin{array}{c}\text { Mean } \\
\text { score }\end{array}$ & SD & $\begin{array}{c}\text { Mini- } \\
\text { mum }\end{array}$ & Q1 & Median & Q3 & $\begin{array}{c}\text { Maxi- } \\
\text { mum }\end{array}$ \\
\hline PFCC-Overall & 3.63 & 0.28 & 2.33 & 3.51 & 3.71 & 3.81 & 4.00 \\
PFCC-Collaboration & 3.49 & 0.30 & 2.44 & 3.33 & 3.56 & 3.67 & 4.00 \\
PFCC-Support & 3.68 & 0.49 & 1.60 & 3.60 & 3.80 & 4.00 & 4.00 \\
Longitudinality & 7.16 & 2.33 & 2.00 & 5.00 & 8.00 & 9.00 & 10.00 \\
Coordination & 6.05 & 2.57 & 0.00 & 4.17 & 6.25 & 8.33 & 10.00 \\
\hline Note: PFCC-Perceptions of Family-Centered Care; SD-Standard Deviation; Q-Quartile.
\end{tabular}

Table 2 - Spearman's correlation between the physical, social and emotional burden score of CSHCN' caregivers and variables related to health care practices, São Carlos, São Paulo, Brazil, 2017- 2018

\begin{tabular}{ccccccc}
\hline & & $\begin{array}{c}\text { PFCC- } \\
\text { Collaboration }\end{array}$ & $\begin{array}{c}\text { PFCC- } \\
\text { Support }\end{array}$ & $\begin{array}{c}\text { PFCC- } \\
\text { Overall }\end{array}$ & $\begin{array}{c}\text { Longitu- } \\
\text { dinality }\end{array}$ & Coordination \\
\hline \multirow{2}{*}{ Burden } & $\mathrm{r}$ & -0.20573 & -0.21258 & -0.15957 & -0.27906 & -0.16441 \\
& $p$ & 0.0337 & 0.0337 & 0.1128 & 0.0323 & 0.2134 \\
& $n$ & 100 & 100 & 100 & 59 & 59 \\
\hline
\end{tabular}

Note: PFCC - Perceptions of Family-Centered Care; $r$-Spearman's correlation coefficient; $p$ - $p$ value; $n$ - number of subjects. 
Table 3 - Univariate linear regression analysis for the physical, social and emotional burden score of CSHCN' caregivers, São Carlos, São Paulo, Brazil, 2017- 2018

\begin{tabular}{lccc}
\hline Variable & Beta (SE)* & $\boldsymbol{p}$ value & $\mathbf{R}^{\mathbf{*} *}$ \\
\hline PFCC/Overall & $-0.16(0.10)$ & 0.113 & 0.0255 \\
PFCC/Collaboration & $-0.21(0.10)$ & 0.040 & 0.0423 \\
PFCC/Support & $-0.23(0.11)$ & 0.034 & 0.0337 \\
Longitudinality & $-0.50(0.22)$ & 0.027 & 0.0830 \\
Coordination & $-0.29(0.22)$ & 0.196 & 0.0291
\end{tabular}

Note: CSHCN - Children with special health needs; PFCC - Perceptions of Family-Centered Care; * Beta-estimate value or slope coefficient in the regression line; $S E$ - beta standard error; ${ }^{* *} R^{2}$ - coefficient of determination (\% of variability of the response variable explained by the independent variable). Variables without normal distribution were ranked.

\section{DISCUSSION}

According to the results, the practice of family-centered care by health services had an influence on the physical, emotional and social burden of CSHCN' caregiver mothers, given the weak negative correlation between the physical, social and physical burden score of CSHCN' caregiver mothers and the perception of family-centered care represented by the variables PFCC-collaboration and PFCC-support. A North American study conducted with families of children with special health needs corroborates this result. In such a study, families who received family-centered care reported better access to health services, fewer hours of direct care and reduced financial burden, factors that certainly eased the burden ${ }^{(22)}$.

In the present investigation, the overall score of the Longitudinality attribute among $\mathrm{CSHCN}^{\prime}$ caregiver mothers was 7.16. According to recommendations of the PCATool manual ${ }^{(19)}$, this value indicates a longitudinal bond between Primary Health Care professionals and caregiver mothers. In a study conducted in northeastern Brazil, was evaluated the Longitudinality attribute among 344 caregivers of children under ten years old enrolled in the family health strategy ${ }^{(23)}$, and was found a lower score than that of the present study. According to the authors, an effective bonding could provide more effective child health care ${ }^{(23)}$. This difference may be related to children's characteristics, who were mostly healthy in the present study.

The aim of a qualitative study conducted with 12 family caregivers of children and adolescents with chronic disease was to understand the perception of continuity and longitudinality of care in the face of a chronic disease. Difficulties were faced for building a permanent partnership between family and the health team in the current health care model and constant complaints from caregivers prevailed ${ }^{(24)}$.

In the multivariate linear regression model, regarding the influence of the Longitudinality attribute in maternal burden, a statistically significant relationship was identified with the physical, social and emotional burden score $(p=0.023)$ of $\mathrm{CSHCN}^{\prime}$ caregivers. In the literature, there are gaps about this direct association, but emphasis is given to the benefits of health care based on Primary Health Care principles. Given this perspective, in a study, were evaluated the potential factors related to hospitalization for pneumonia in children under five years old, and the quality of primary health care was identified as a protective factor for hospitalization ${ }^{(25)}$. Therefore, establishing a relationship of proximity and trust between $\mathrm{CSHCN}^{\prime}$ caregiver mothers and Primary Health Care professionals can positively influence the clinical conditions of CSHCN and, consequently, minimize the mothers' burden.

In the present study, results for the health care practice of care coordination showed a score below 6.6, which is classified as unsatisfactory in the PCATool manual ${ }^{(19)}$. This fact can be concerning since, according to the literature, $\mathrm{CSHCN}$ require more health services than children with typical development so, they have a greater need for care coordination ${ }^{(26)}$. The weak negative correlation between care coordination and the identified burden can be explained by the perspective that establishing an integrated health service network and care coordination would optimize access to services and inputs, avoid fragmentation of care, duplication of care services and reduce emergency care and hospitalizations. The combination of all these aspects would reduce the negative experiences that increase the burden of $\mathrm{CSHCN}^{\prime}$ caregivers ${ }^{(27)}$.

\section{Study limitations}

A limitation of the study was its cross-sectional design that restricts the identification of cause and effect relationships. Another relevant limitation was using the instrument that measured parents' perceptions of family-centered care. Such an instrument was initially designed for parents of hospitalized children, but as in this study it was used for a general evaluation of the perceptions of family-centered care, this choice may have led to misinterpretations. These limitations signal the importance of developing new studies.

\section{Contributions to the area of nursing, health or public policy}

This study contributed as it shifted health care practices to the centrality of care. Identifying the positive repercussions of care that goes beyond technological knowledge can support future transformations in care from the establishment of shared, longitudinal and integrated care between families and health services.

\section{CONCLUSIONS}

The aim of the present study was to explore the influence of health care practices on the physical, emotional and social burden of CSHCN' caregiver mothers. The results presented reached the proposed objectives. The conclusion was that health care practices analyzed had a negative correlation with the burden. Caregiver mothers who had a positive perception about the support and collaboration domains of family-centered care felt less burdened. Caregiver mothers who identified a lower presence of the Longitudinality attribute of Primary Health Care had higher burden scores.

\section{FUNDING/ACKNOWLEDGEMENT}

The publication of this article received financial support from the Coordenação de Aperfeiçoamento de Pessoal de Nível Superior (CAPES). 


\section{REFERENCES}

1. Quach J, Jansen PW, Mensah FK, Wake M. Trajectories and outcomes among children with special health care needs. Pediatrics [Internet]. 2015 [cited 2018 Nov 10];135(4):e842-e850. Available from: http://pediatrics.aappublications.org/content/135/4/e842.

2. Arrué AM, Neves ET, Magnago TSBS, Cabral IE, Gama SGN, Hökerberg YHM. Tradução e adaptação do Children with Special Health Care Needs Screener para português do Brasil. Cad Saúde Pública. 2016;32(6): e00130215. doi: 10.1590/0102-311X00130215.

3. Kuhlthau KA, Bloom S, Van Cleave J, Knapp AA, Romm D, Klatka K, et al. Evidence for family-centered care for children with special health care needs: a systematic review. Acad Pediatr. 2011;11(2):136-43. doi: 10.1016/j.acap.2010.12.014

4. Cabral IE, Moraes JRMM. Family caregivers articulating the social network of a child with special health care needs. Rev Bras Enferm. 2015;68(6):1078-85. doi: 10.1590/0034-7167.2015680612i

5. Okido ACC, Zago MMF, Lima RAG. Care for technology dependent children and their relationship with the health care systems. Rev LatinoAm Enfermagem. 2015;23(2):291-8. doi: 10.1590/0104-1169.0258.2554

6. Romley JA, Shah AK, Chung PJ, Elliott MN, Vestal KD, Schuster MA. Family-provided health care for children with special health care needs. Pediatrics [Internet]. 2017 [cited 2019 Jan 15];139(1): e20161287. Available from: http://pediatrics.aappublications.org/content/ pediatrics/139/1/e20161287.full.pdf

7. Macedo EC, Silva LR, Paiva MS, Ramos MN. Burden and quality of life of mothers of children and adolescents with chronic illnesses: an integrative review. Rev Latino-Am Enfermagem [Internet]. 2015 [cited 2019 Jan 13];23(4):769-77. Available from: http://www.scielo.br/pdf/ rlae/v23n4/0104-1169-rlae-23-04-00769.pdf

8. Pilapil M, Coletti DJ, Rabey C, DeLaet D. Caring for the caregiver: supporting families of youth with special health care needs. Curr Probl Pediatr Adolesc Health Care [Internet]. 2017 [cited 2018 Nov 08]; 47(8):190-199. Available from: https://www.sciencedirect.com/science/ article/pii/S1538544217301396.

9. Medrano GR, Berlin KS, Davies WH. Utility of the PedsQL ${ }^{\mathrm{TM}}$ family impact module: assessing the psychometric properties in a community sample. Qual Life Res [Internet]. 2013 [cited 2019 Jan 13];22(10):2899-907. Available from: https://link.springer.com/article/10.1007/ s11136-013-0422-9

10. Ufer LG, Moore JA, Hawkins K, Gembel G, Entwistle DN, Hoffman D. Care coordination: empowering families, a promising practice to facilitate medical home use among children and youth with special health care needs. Matern Child Health J [Internet]. 2018 [cited 2019 Jan 16];22(5):648-59. Available from: https://link.springer.com/article/10.1007/s10995-018-2477-2

11. McClanahan R, Weismuller PC. School nurses and care coordination for children with complex needs: an integrative review. J Sch Nurs [Internet]. 2015 [cited 2018 Dec 21];31(1):34-43. Available from: https://journals.sagepub.com/doi/pdf/10.1177/1059840514550484

12. Mikkelsen G, Frederiksen K. Family-centred care of children in hospital-a concept analysis. J Adv Nurs [Internet]. 2011 [cited 2018 Nov 23];67(5):1152-62. Available from: https://onlinelibrary.wiley.com/doi/epdf/10.1111/j.1365-2648.2010.05574.x

13. Baratieri T, Marcon SS. Longitudinality of care: perceptions of the nurses that work at the family health strategy. Esc Anna Nery [Internet]. 2011 [cited 2018 Dec 15]; 15(4):802-10. doi: 10.1590/S1414-81452011000400020

14. Hulley SB, Cummings SR, Browner WS, Grady DG, Newman TB. Delineando a pesquisa clínica. 4aed. Artmed; 2015.

15. Presidência da República (BR). Constituição. Lei n 8.069, de 13 de julho de 1990. Dispõe sobre o Estatuto da Criança e do Adolescente e dá outras providências [Internet]. Diário Oficial da União, 1990[cited 2018 Jun 13]. Available from: http://www.planalto.gov.br/ccivil_03/leis/ 18069.htm

16. Stevens JP. Applied Multivariate Statistics for the Social Sciences. 2 ed. Hillsdale, NJ: Erlbaum,1992.

17. Scazufca M. Brasilian version of the Burden Interview scale for the assessment of burden of care in carers of people with mental illnesses. Rev Bras Psiquiatr. 2002;24(1):12-17. doi: 10.1590/S1516-44462002000100006

18. Silva TON, Alves LB, Balieiro MM, Mandetta MA, Tanner A, Shields L. Cross-cultural adaptation of an instrument to measure the familycentered care. Acta Paul Enferm [Internet]. 2015 [cited 2018 Jun 28];28(2):107-12. doi: 10.1590/1982-0194201500019

19. Ministério da Saúde (BR). Secretaria de Atenção em Saúde. Departamento de Atenção Básica. Manual do instrumento de avaliação da atenção primária à saúde: Primary Care Assessment Tool Pcatool. Brasília (DF): Ministério da Saúde, 2010a. 80 p.: il. - (Série A. Normas e Manuais Técnicos).

20. Devellis RF. Scale Development: theory and apllications. Newbury Park, CA: SAGE Publications. 1991.

21. Fisher LD, Belle GV. Biostatistics: a methodology for the health sciences. New York: Wiley, 1993. $991 \mathrm{p}$.

22. Kuo DZ, Cohen E, Agrawal R, Berry JG, Casey PH. A national profile of caregiver challenges among more medically complex children with special health care needs. Arch Pediatr Adolesc Med [Internet]. 2011 [cited 2019 Jan 14];165(11):1020-6. Available from: https:// jamanetwork.com/journals/jamapediatrics/article-abstract/1107633

23. Vaz EM, Magalhães RK, Toso BR, Reichert AP, Collet N. Longitudinality in childcare provided through Family Health Strategy. Rev Gaúcha Enferm [Internet]. 2015 [cited 2019 Feb 12];36(4):49-54. Available from: https://www.seer.ufrgs.br/RevistaGauchadeEnfermagem/article/ view/51862/35663 
24. Nóbrega VM, Reichert AP, Viera CS, Collet N. Longitudinality and continuity of care for children and adolescents with chronic diseases. Esc Anna Nery [Internet]. 2015 [cited 2019 Fev 13];19(4):656-63. doi: 10.5935/1414-8145.20150088

25. Pina JC, Moraes SA, Freitas IC, Mello DF. Role of Primary Health Care in child hospitalization due to pneumonia: a case-control study. Rev Latino-Am Enfermagem [Internet]. 2017 [cited 2019 Jan 30];25:e2892. Available from: http://www.scielo.br/pdf/rlae/v25/0104-1169-rlae25-e2892.pdf

26. Sannicandro T, Parish SL, Son E, Powell RM. Health care changes for children with special health care needs, 2005-2011. Matern Child Health J [Internet]. 2017 [cited 2018 Dec 21];21(3):524-30. Available from: https://link.springer.com/article/10.1007/s10995-016-2136-4

27. Boudreau AA, Goodman E, Kurowski D, Perrin JM, Cooley WC, Kuhlthau K. Care coordination and unmet specialty care among children with special health care needs. Pediatrics [Internet]. 2014 [cited 2018 Dec 13];133(6):1046-53. Available from: http://lpfch.org/sites/default/files/ care-coordination-and-unmet-specialty-care-among-children-with-special-health-care-needs.pdf 